\title{
THE USE OF AN IMMUNOPEROXIDASE TECHNIQUE TO INVESTIGATE BY LIGHT AND ELECTRON MICROSCOPY THE SITES OF BINDING OF CLOSTRIDIUM WELCHII TYPE-D EPSILON TOXIN IN MICE
}

\author{
D. BUXTON \\ Department of Pathology, Moredun Research Institute, \\ 408 Gilmerton Road, Edinburgh EH17 $7 J H$

\section{Plate XXIV}

CLOSTRIDIUM WELCHII type-D toxin damages the "blood-brain barrier" in mice, causing the blood vessels to become permeable to intravenously administered horseradish peroxidase (HRP) (Gardner, 1974; Morgan, Kelly and Buxton, 1975). The leakage produced in this way can be prevented by the prior administration of formalinised epsilon prototoxin which is able to block the toxin receptor sites (Buxton, 1976). Attempts to demonstrate the toxin in the tissues by immunofluorescence and immunoperoxidase techniques were unsuccessful; however, as epsilon toxin and formalinised epsilon prototoxin are antigenically identical (Habeeb, 1969) and compete for the same receptor sites (Buxton, 1976), it was decided to use formalinised prototoxin in further studies. This allowed the administration of an increased amount of antigen which was identified in the tissues by means of an immunoperoxidase technique to reveal the binding sites.

\section{MATERIALS AND METHODS}

Male Porton/ADR mice aged 4 weeks were given an intravenous dose of the epsilon prototoxin of $C$. welchii type D (Dr R. O. Thomson, Wellcome Research Laboratories) in which no alpha toxin (lecithinase) was demonstrable by the tube test (Cruickshank, 1965).

Formalinised epsilon prototoxin. Prototoxin dissolved in $1 \%$ peptone water, $\mathrm{pH} 7 \cdot 6$, at a concentration of $10 \mathrm{mg}$ per $\mathrm{ml}$ was formalinised (final concentration of formaldehyde $0.12 \%$ ) and incubated at $37^{\circ} \mathrm{C}$ for 7 days. Control solutions were similar except that the epsilon prototoxin was omitted.

Immunoperoxidase reagents. Antiserum to epsilon prototoxin was produced in a rabbit by administering repeated doses of the antigen in Freund's complete adjuvant over a period of 6 months. Antiserum to normal rabbit IgG was produced in sheep. Normal rabbit serum was collected and IgG was separated from a proportion of it by DEAE cellulose chromatography. Each $1-\mathrm{ml}$ volume, containing $5 \mathrm{mg}$ of purified IgG, was then conjugated with $12 \mathrm{mg}$ of HRP (Sigma Type VI; Sigma Chemical Company, St Louis, USA) by the method of Avrameas (1969).

Experimental procedure. Mice were given a 1-ml intravenous dose of formalinised prototoxin or formalinised peptone water. One hour after inoculation the mice were anaesthetised and perfused with $10 \%$ formol saline, $p \mathrm{H} 7 \cdot 0$, as described by Morgan and Kelly (1974).

Received 30 Nov. 1977; accepted 14 Dec. 1977.

J. MED. MICROBIOL.-VOL. 11 (1978) 
After perfusion, blocks of brain (one coronal slice at a level of the thalamus and another through the cerebellum and pons), heart, lung, liver, spleen, kidneys, intestines and skeletal muscle were immersed in fresh $10 \%$ buffered formol saline for a further 7 days; they were then dehydrated through graded alcohols, cleared in toluene and embedded in paraffin wax.

Staining reaction. An indirect immunoperoxidase method adapted from the work of Burns (1975) and Petrusz et al. (1975) was used. Sections $6 \mu \mathrm{m}$ thick were brought to alcohol and treated with $0.5 \%$ hydrogen peroxide in methanol for $30 \mathrm{~min}$. to block endogenous peroxidase activity. The sections were washed in $0.01 \mathrm{M}$ phosphate-buffered saline (PBS)

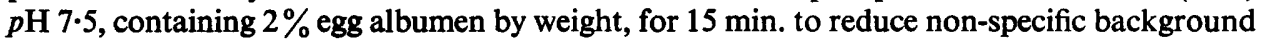
staining and then treated for $30 \mathrm{~min}$. with each of the following reagents: rabbit antitoxin; sheep anti-rabbit IgG; a conjugate of normal rabbit IgG and HRP. All serum dilutions and rinses between each step were made with PBS containing albumen $2 \%$, and the final rinse was with $0.05 \mathrm{M}$ tris-HCl buffer, $p \mathrm{H} \mathrm{7.6}$. The end product was then stained with a solution of 3,3'-diaminobenzidine and $0.01 \%$ hydrogen peroxide in $0.05 \mathrm{M}$ tris- $\mathrm{HCl}$ buffer $p \mathrm{H} 7.6$ for 5 min., counterstained lightly with haematoxylin, dehydrated, cleared and mounted. Each step was appropriately controlled.

Preparation for electron microscopy. Sections of mouse kidney, $20 \mu \mathrm{m}$ thick, were cut and mounted on the roughened top surface of Araldite cylinders $(1 \mathrm{~cm}$ high and $1 \mathrm{~cm}$ in diameter). After being dewaxed for exactly $5 \mathrm{~min}$. in xylene, they were immersed for $2 \mathrm{~min}$. in absolute alcohol and treated in the same manner as the glass-mounted sections. After the 3,3'diaminobenzidine stage they were rinsed well in water and left overnight in $0 \cdot 1 \mathrm{M}$ phosphate buffer, $p \mathrm{H} \mathrm{7 \cdot 4}$. They were then treated with $1 \%$ osmium tetroxide in phosphate buffer for $1 \mathrm{~h}$, rinsed well in several changes of the same buffer and dehydrated through graded alcohols. After two washes of exactly $5 \mathrm{~min}$. each in epoxy-propane the sections were immersed in liquid Araldite for $24 \mathrm{~h}$. Fresh Araldite was then layered on, to a depth of $0.5 \mathrm{~mm}$, before polymerisation at $60^{\circ} \mathrm{C}$ for $72 \mathrm{~h}$. The length of time for which the Araldite cylinders were exposed to xylene and epoxy-propane proved critical, as longer exposure destroyed the Araldite and shorter exposure was insufficient for the treatment of the tissues. Araldite sections $1 \mu \mathrm{m}$ thick were cut and stained with a weak solution of Giemsa stain. Ultrathin sections were cut and mounted on collodion-coated grids and stained with lead acetate before they were viewed and photographed in a Siemens Elmiskop I electron microscope.

\section{RESULTS}

The sections taken from the mice given an intravenous dose of formalinised prototoxin gave specific positive results.

In the brain there were clearly-defined dark-brown deposits of reaction product on the luminal surface of the vascular endothelium of many of the blood vessels in the thalamus, cerebral cortex, cerebellar white matter cores, cerebellar peduncles, pons, and cerebral and cerebellar meninges (fig. 1).

In the kidney there were dense deposits of reaction product on the luminal surface of many of the lining cells of the loops of Henle and the distal convoluted tubules (fig. 2) whilst only small amounts were present on the luminal surface of the capillaries. No reaction product was associated with the glomeruli, proximal convoluted tubules or collecting ducts. Examination of the kidney by electron microscopy confirmed the light microscopic findings and in addition showed that the reaction product, when present, was very closely associated with the luminal surface of the cytoplasmic membranes of the above cells (fig. 3).

The sections of liver revealed reaction product associated with the luminal surface of the sinusoids, many of the centrilobular veins, a few large veins and several of the bile ducts. 


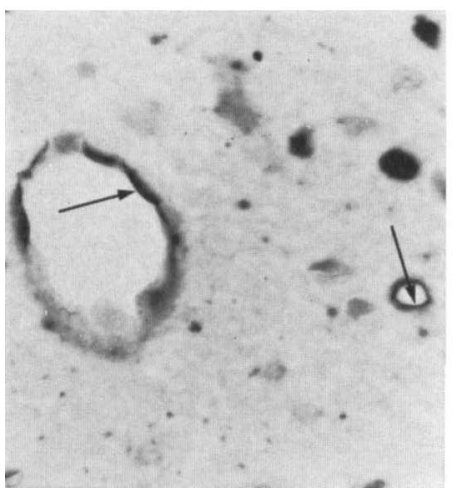

FIG. 1.-Blood vessel in thalamus of mouse given intravenous formalinised epsilon prototoxin showing HRP reaction product on luminal surface of vascular endothelium (arrows). Immunoperoxidase. $\times 480$.

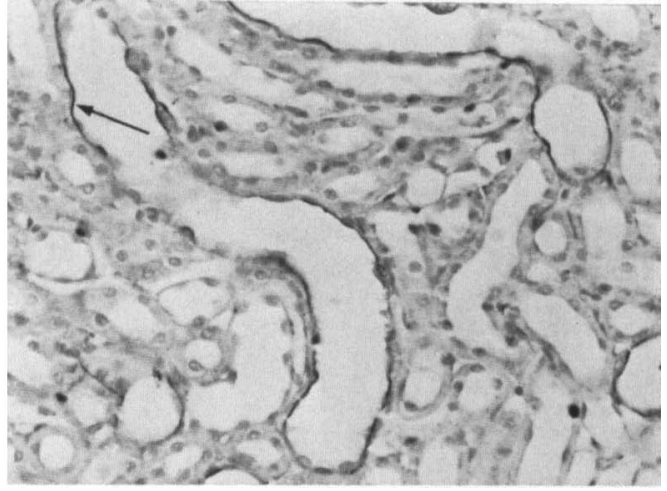

FIG. 2.-Kidney of mouse given intravenous formalinised epsilon prototoxin showing HRP reaction product on luminal surface of renal tubules (arrow). Immunoperoxidase. $\times 300$.

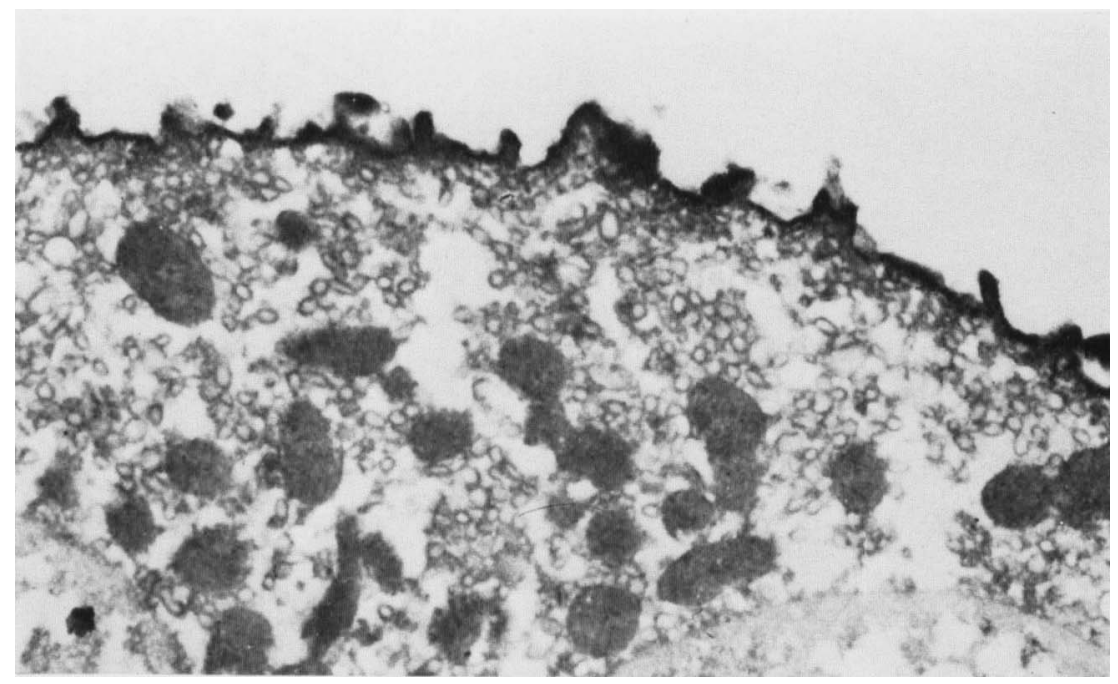

FIG. 3.-Kidney of mouse given intravenous formalinised epsilon prototoxin showing HRP reaction product on luminal surface of cell lining renal tubules. Electromicrograph. Immunoperoxidase. $\times 15000$. 
The sections of lung showed only sparse deposits of reaction product on the luminal surface of some of the larger veins and only light deposits were found on the luminal surface of the capillaries of the heart.

Examination of the small and large intestines, smooth muscle (intestinal) and skeletal muscle revealed no reaction product.

The positive findings above were absent from all control preparations.

\section{Discussion}

The work described in this paper was concerned with locating the receptor sites for $C$. welchii type-D epsilon toxin in mouse tissues by light and electron microscopy.

The demonstration of specific antigens by electron microscopy depends upon a compromise between good fixation and the retention of the immunoreactivity of the antigen being studied. Several different techniques have been described in the literature. One of the longest established methods (Zacks and Sheff, 1968) is the application of HRP-labelled specific antiserum to cryostat sections, and this has the advantage of requiring only one antibody to penetrate the tissue, but antigen-specific conjugate has to be specially prepared and the method is often less sensitive than indirect methods.

Laliberte et al. (1975) used an indirect immunoperoxidase method on $40-\mu \mathrm{m}$ tissue sections and found that staining took almost 4 days because of the poor penetration of the tissues by the antisera. Webb and Dorling (1972) treated glass-mounted $10-\mu \mathrm{m}$ cryostat sections by the indirect method and found that staining could be achieved quite rapidly although ultrastructural detail was poor.

Kawarai and Nakane (1970) avoided the problem of poor penetration of tissues by antisera by mounting ultrathin methacrylate-embedded sections on coated grids, removing the methacrylate and staining the tissue on the grid. This method allows the use of serial sections and the demonstration of one antigen on one section and other antigens on succeeding sections.

The method used in the present study involved the application of a routine immunoperoxidase technique to a dewaxed paraffin section mounted on the end of an Araldite cylinder. The main disadvantage of this method as of the other methods mentioned was the relatively poor intracellular detail at high magnification. The chief advantages of the method are that appropriate areas can be preselected, tissues are easily stored as paraffin blocks, uniform serial sections can be rapidly prepared and the optimal serum dilutions necessary for the demonstration of antigen can be found before examination with the electron microscope. The method also allows the use of indirect staining methods, as each layer of serum need only be applied for a relatively short time.

In the present study, clearly defined deposits of HRP reaction product were demonstrated on the luminal surface of the vascular endothelium in certain organs, particularly the brain, on the luminal surface of the cells lining the loops of Henlé and distal convoluted tubules in the kidney, and in the hepatic sinusoids.

As these deposits were absent from duplicate sections treated with normal 
rabbit serum in place of antitoxin and absent from tissues taken from the control mice, it is thought that they indicated the sites of binding of the formalinised epsilon prototoxin. As formalinised epsilon prototoxin and epsilon toxin have been shown to compete for the same receptor sites (Buxton, 1976) it is considered that the reaction product is located on the receptor sites for $C$. welchii type-D epsilon toxin and that these receptors are on the outer surface of the cell membrane.

\section{SUMMARY}

Mice were given an intravenous dose of formalinised $C$. welchii type-D epsilon prototoxin and an immunoperoxidase technique was used to demonstrate this antigen in the tissues. The antigen was found to bind to the luminal surface of the endothelial lining of certain blood vessels, to the luminal surface of the cells lining the loops of Henlé and distal convoluted tubules in the kidney, and to the hepatic sinusoids. As it has been shown previously that formalinised epsilon prototoxin and epsilon toxin can compete for the same receptor sites it is postulated that the binding sites demonstrated represent the location of the receptors for $C$. welchii type-D epsilon toxin.

The advice of Dr R. M. Barlow and Professor J. G. Collee is gratefully acknowledged as is the technical assistance of Mrs J. Finlayson, Mr J. Wight and Mr E. Gray.

\section{REFERENCES}

Avrameas, S. 1969. Coupling of enzymes to proteins with glutaraldehyde. Use of the conjugates for the detection of antigens and antibodies. Immunochemistry, 6, 43.

BURNS, J. 1975. Background staining and sensitivity of the unlabelled antibody-enzyme (PAP) method. Comparison with the peroxidase labelled antibody sandwich method using formalin fixed paraffin embedded material. Histochemistry, 43, 291.

Buxton, D. 1976. Use of horseradish peroxidase to study the antagonism of Clostridium welchii ( $\mathrm{Cl}$. perfringens) type $\mathrm{D}$ epsilon toxin in mice by the formalinized epsilon prototoxin. J. comp. Path., 86, 67.

Cruickshank, R. 1965. Medical microbiology, 11 th ed., Edinburgh and London, p. 839.

GARDNER, D. E. 1974. Brain oedema: an experimental model. Br. J. exp. Path., 55, 453.

HABEEB, A. F. S. A. 1969. Studies on $\varepsilon$-prototoxin of Clostridium perfringens type D. I. Purification methods: evidence for multiple forms of $\varepsilon$-prototoxin. Archs Biochem. Biophys., 130, 430.

Kawarai, Y. AND Nakane, P. K. 1970. Localization of tissue antigens on the ultrathin sections with peroxidase-labeled antibody method. J. Histochem. Cytochem., 18, 161.

Laliberte, F., Sapin, C., Druet, P. and Bariety, J. 1975. Ultrastructural study by immunoperoxidase of a rat membranous glomerulonephritis. J. Ultrastruct. Res., 50, 150.

MorGaN, K. T. AND KeLLY, B. G. 1974. Ultrastructural study of brain lesions produced in mice by the administration of Clostridium welchii type D toxin. J. comp. Path., 84, 181.

Morgan, K. T., Kelly, B. G. AND Buxton, D. 1975. Vascular leakage produced in the brains of mice by Clostridium welchii type D toxin. J. comp. Path., 85, 461.

Petrusz, P., Di Meo, P., Ordronneau, P., Weaver, C. ANd Keefer, D. A. 1975. Improved immunoglobulin-enzyme bridge method for light microscopic demonstration of hormonecontaining cells of the rat adenohypophysis. Histochemistry, 46, 9.

Webb, J. A. AND Dorling, J. 1972. The use of peroxidase-labelled antiglobulin for ultrastructural localization of tissue antigens reacting with serum antibodies. J. immun. Meth., 2, 145.

ZACKS, S. I. AND ShEFF, M. F. 1968. Tetanus toxin: fine structure localization of binding sites in striated muscle. Science, N.Y., 159, 643. 